\title{
KINERJA APARATUR PEMERINTAH DESA DALAM PENGELOLAAN ADMINISTRASI DESA
}

(Studi Di Desa Tumbang Kaman Kecamatan Sanaman Mantikei Kabupaten Katingan)

\section{Bron}

\begin{abstract}
Good government village is depending on the performance of government village employee. Government village employee consist of: village head and staff that the most important person who in charge of managing the administration.

Tumbang Kaman government village as the lowest unit of government have obligation to make good performance employee through administration management, therefore it has been granted as the champion of village competition in 2013.

The research uses descriptive-qualitative methode. Collecting data technic is being done by observation, interview, and documentation. The data analysis technic uses interactive model by Miles and Huberman.

Depend on the fact from the field, found some conclusion that: 1) Good government employee performance have achieved observed by quality, quantity, time work, and tim work. 2) Unsupporting factors in administration management was not meaningfull, but it still there: lower skill administration of the government village employee, the salary should be increase. Supporting factors are: the infrastructure are available well in Tumbang Kaman village and also tim work have achieved well.
\end{abstract}

Keywords: Performance, Government Employee, Administration Management

\section{PENDAHULUAN}

Menurut perspektif sosiologis, desa adalah komunitas yang menempati wilayah tertentu dimana warganya saling mengenal satu sama lain dengan baik, bercorak homogen, dan banyak bergantung pada alam. Menurut kacamata politik, desa dipahami sebagai organisasi kekuasaan yang memiliki kewenangan tertentu dalam struktur pemerintahan negara (Pratikno,2000). Kajian-kajian politik juga telah memiliki tradisi membahas desa dalam topik otonomi dan demokrasi. Pembicaraan mengenai desa sebagai komunitas yang otonom menghasilkan sejumlah gagasan mengenai tipe desa seperti self-governing community (berpemerintahan sendiri), local self government (pemerintahan lokal yang otonom) dan local state government (pemerintahan negara tingkat lokal) (Sutoro,2006). Sedangkan pembicaraan yang menghubungkan desa dalam topik demokrasi, umumnya melihat desa sebagai republik mini yang sanggup melangsungkan pengurusan publik dan pergantian kepemimpinan secara demokratis. Desa adalah republik kecil yang self contained. Ukurunnya tidak ditekankan pada pemenuhan atas tiga cabang kekuasaan yakni legislatif, eksekutif, yudikatif. Ukurannya dijatuhkan pada pelembagaan kultur dan tradisi demokrasi desa dianggap lebih penting ketimbang pengaturan dan penciptaan institusi-institusi formal demokrasi (Haris, Makalah).

Setidaknya ada dua dimensi permasalahan yang dapat diidentifikasi tentang desa. Pertama, masalah seputar desa sebagai suatu komunitas politik tertentu. Kedua, masalah seputar pemerintahan desa itu sendiri. Dalam hubungan yang pertama, terdapat persoalan pengendalian dan depolitisasi yang merembet pada kewenangan desa termasuk dalam perolehan dan alokasi dana desa juga soal pemekaran. Dalam kaitannya dengan permasalahan yang kedua, muncul praktek penyeragaman struktur pemerintahan desa yang terpaksa sering berhadapan dengan struktur organisasi lokal/adat; soal sumber daya manusia yang terbatas 
dan berkualifikasi rendah dalam menjalankan tugas dan kewenangannya juga tentang peraturan desa.

Pembangunan nasional yang terdiri atas banyak aspek pengelolaannya melibatkan segenap aparat pemerintahan, baik di tingkat pusat maupun di tingkat daerah bahkan sampai di tingkat desa. Unsur atau aparat dimaksud hendaknya memiliki kemampuan baik dalam menjalankan tugasnya. Tepatlah kiranya jika wilayah desa menjadi sasaran penyelenggaraan pemerintahan dan pembangunan, mengingat pemerintahan desa merupakan pusat pemerintahan terendah dalam struktur pemerintahan Indonesia yang sangat menentukan berhasil atau tidaknya pelaksanaan pembangunan nasional yang menyeluruh.

Mempertimbangkan begitu banyaknya aspek atau bidang yang akan dibangun pada pemerintahan tingkat desa tersebut, maka salah satu aspek yang seharusnya terlebih dahulu perlu dibangun adalah peningkatan kemampuan aparatur pemerintah desa dalam pelaksanaan tugas-tugas administrasi desa.

Hal tersebut sangat penting, karena pemerintah desa beserta aparatnya adalah sebagai administrator penyelenggara utama aktivitas pemerintahan, pembangunan, dan kemasyarakatan maupun sebagai pembina ketentraman dan ketertiban di wilayah kekuasaannya. Karena itu, peranan mereka penting dalam menciptakan ketentraman dan ketertiban di wilayah kekuasaannya. Karena itu, peranan mereka penting dan banyak menentukan maju mundurnya suatu unit pemerintahan. Untuk itu diperlukan aparatur pemerintah desa yang mampu dan dapat bekerjasama dalam pelaksanaan tugas yang menjadi tanggung jawabnya.

Keberadaan aparatur pemerintah desa yang juga diserahi tugas dibidang administrasi menduduki yang posisi sangat penting karena sebagai organ pemerintahan yang paling bawah mengetahui secara pasti segala kondisi dan permasalahan yang ada diwilayahnya, maka input pada pemerintah kecamatan yang menyangkut berbagai keterangan dan informasi sangatlah dibutuhkan dalam pengambilan kebijaksanaan daerah maupun nasional untuk kebutuhan pembangunan secara menyeluruh.

Sehubungan dengan hal tersebut diatas, Suryaningrat (1992:108) mengemukakan bahwa "Desa sebagai bahan keterangan dan sumber data dan bahan keterangan yang diperoleh dari desa seringkali digunakan untuk rencana daerah oleh karena itu data buatan atau data keterangan harus dihindarkan karena dapat menggagalkan tujuan negara".

Dengan demikian aparat desa dalam pelaksanaan tugas sehari-hari, terutama yang berhubungan dengan penyajian data dan informasi yang dibutuhkan, semakin dituntut adanya kerja keras dan dan kemampuan yang optimal guna memperlancar pelaksanaan tugas pemerintahan.

Belum tersedianya informasi atau pencatatan administrasi secara baik sebagaimana tersebut diatas, maka hal itu terjadi karena adanya pengaruh berbagai faktor, antara lain terutama faktor kemampuan sumber daya aparat desa sebagai penyelenggara belum optimal. Dalam konteks penyelenggaraan pemerintahan desa yang terpenting adalah bagaimana aparatur pemerintah desa mampu meningkatkan kesejahteraan rakyatnya, mampu memberikan pelayanan kepada masyarakat desa, dan mampu meningkatkan daya saing desanya. Hal tesebut hanya mungkin terwujud apabila urusan yang menjadi kewenangan desa dapat terlaksana dengan baik. Tidak dapat dipungkiri, bahwa dalam implementasinya terdapat berbagai permasalahan yang langsung maupun tidak langsung menghambat pelaksanaan urusan-urusan pemerintahan tersebut.

Kapasitas yang masih rendah merupakan bagian dari permasalahan yang ditunjukkan di lapangan. Diantaranya masih belum optimalnya aspek kelembagaan, sumberdaya manusia, maupun manajemen pemerintahan desa.

Kapasitas aparatur pemerintah desa yang masih rendah merupakan sumber permasalahan dari kinerja pemerintah desa secara keseluruhan. Menurut Sudarmanto 
(2009:7) konsep kinerja setidaknya dapat dibagi menjadi 3 (tiga) tingkatan yaitu: kinerja organisasi, kinerja proses, dan kinerja individu. Selanjutnya pengertian kinerja juga dapat dibagi menjadi 2 (dua) yaitu kinerja dalam pengertian sebagai hasil dan kinerja dalam pengertian sebagai perilaku. Dengan pengertian ini, maka seyogyanya kita dapat memahami kinerja secara lebih kompleks.

Desa Tumbang Kaman Kecamatan Sanaman Mantikei Kabupaten Katingan adalah salah satu entitas pemerintahan yang ada di Kabupaten Katingan. Pemerintah Desa Tumbang Kaman memiliki struktur organisasi yang lengkap dalam menyelenggarakan pemerintahan dan pelayanan publik kepada masyarakat. Kinerja aparatur pemerintah Desa Tumbang Kaman sebagaimana yang diobservasi menunjukkan penyelenggaraan administrasi yang dianggap penulis cukup baik. Selanjutnya penulis tertarik untuk mengkaji secara lebih mendalam, apakah fenomena yang dilihat tersebut dapat dibuktikan dan dapat diukur sebagaimana konsep kinerja yang sebenarnya.

Untuk itu pada kesempatan ini penulis tertarik untuk mengajukan usulan penelitian berjudul "KINERJA APARATUR PEMERINTAH DESA TUMBANG KAMAN DALAM PENGELOLAAN ADMINISTRASI DESA (Studi Di Desa Tumbang Kaman Kecamatan Sanaman Mantikei Kabupaten Katingan)". Oleh karena itu, tujuan penelitian ini dapat dikategorikan menjadi 2 bagian yaitu:

1. Untuk mengkaji dan mendeskripsikan kinerja aparatur Pemerintah Desa Tumbang Kaman dalam pengelolaan administrasi desa.

2. Untuk mengkaji dan mendeskripsikan faktor penghambat dan faktor pendorong kinerja aparatur Pemerintah Desa Tumbang Kaman dalam pengelolaan administrasi desa.

\section{TINJAUAN PUSTAKA}

\section{Pengertian dan Ruang Lingkup Kinerja}

Konsep kinerja pada dasarnya merupakan perubahan atau pergeseran paradigma dari konsep produktivitas. Pada awalnya, orang seringkali menggunakan istilah produktivitas untuk menyatakan kemampuan seseorang atau organisasi dalam mencapai tujuan atau sasaran tertentu. Menurut Andersen (1995) dalam Sudarmanto (2009:7), paradigma produktivitas yang baru adalah paradigma kinerja secara aktual yang menuntut pengukuran secara aktual keseluruhan kinerja organisasi, tidak hanya efisiensi atau dimensi fisik, tetapi juga dimensi non fisik (intangible).

Terkait dengan konsep kinerja, Rummler dan Brache (1995) dalam Sudarmanto (2009:7) mengemukakan ada 3 (tiga) level kinerja, yaitu:

1. Kinerja organisasi; merupakan pencapaian hasil (outcome) pada level atau unit analisis organisasi. Kinerja pada level organisasi ini terkait dengan tujuan organisasi, rancangan organisasi, dan manajemen organisasi.

2. Kinerja proses; merupakan kinerja pada proses tahapan dalam menghasilkan produk atau pelayanan. Kinerja pada level proses ini dipengaruhi oleh tujuan proses, rancangan proses, dan manajemen proses.

3. Kinerja inividu/pekerjaan; merupakan pencapaian atau efektivitas pada tingkat pegawai atau pekerjaan. Kinerja pada level ini dipengaruhi oleh tujuan pekerjaan, rancangan pekerjaan, dan manajemen pekerjaan serta karakteristik individu.

Dalam berbagai literatur, pengertian tentang kinerja sangat beragam. Akan tetapi, dari berbagai perbedaan pengertian, dapat dikategorikan dalam dua garis besar pengertian dibawah ini;

1. Kinerja merujuk pengertian sebagai hasil. Dalam konteks, Bernardin $(2001 ; 143)$ dalam Sudarmanto (2009:8) menyatakan bahwa kinerja merupakan catatan hasil yang 
diproduksi (dihasilkan) atas fungsi pekerjaan tertentu atau aktivitas-aktivitas selama periode waktu tertentu. Dari definisi tersebut, Bernardin menekankan pengertian kinerja sebagai hasil, bukan karakter sifat (trait) dan perilaku. Pengertian kinerja sebagai hasil juga terkait dengan produktivitas dan efektivitas (Ricard, 2003) dalam Sudarmanto $(2009 ; 8)$. Produktivitas merupakan hubungan antara jumlah barang dan jasa yang dihasilkan dengan jumlah tenaga kerja, modal, dan sumber daya yang digunakan dalam produksi itu (Miner, 1988) dalam Sudarmanto (2009;8).

2. Kinerja merujuk pengertian sebagai perilaku. Terkait dengan kinerja sebagai perilaku, Murphy (1990) dalam Sudarmanto (2009;8) menyatakan bahwa kinerja merupakan seperangkat perilaku yang relevan dengan tujuan organisasi atau unit organisasi tempat orang bekerja. Pengertian kinerja sebagai perilaku juga dikemukakan oleh Mohrman (1989), Campbell (1993), Cardy dan Dobbins (1994), Waldman (1994) (dalam Ricard,2002) dalam Sudarmanto (2009;9). Kinerja merupakan sinonim dengan perilaku. Kinerja adalah sesuatu yang secara aktual orang kerjakan dan dapat diobservasi. Dalam pengertian ini, kinerja mencakup tindakan-tindakan dan perilaku yang relevan dengan tujuan organisasi. Kinerja bukan konsekuensi atau hasil tindakan, tetapi tindakan itu sendiri (Campbell, 1993 dalam Ricard, 2003) dalam Sudarmanto (2009;9).

\section{Pengukuran Kinerja}

Untuk dapat melakukan kinerja dengan baik, banyak pakar atau ahli yang berpendapat tentang standar kinerja yang dapat digunakan, tetapi kebanyakan pendapatnya bervariasi. Martin dan Bartol (dalam Bohlander, dkk. 2002) dalam Sudarmanto $(2009 ; 9)$ menyatakan bahwa standar kinerja seharusnya didasarkan pada pekerjaan, dikaitkan dengan persyaratan yang dijabarkan dari analisis pekerjaan, dan tercermin dalam deskripsi pekerjaan dan spesifikasi pekerjaan.

Bufford, 1998 (dalam Werther \& Davis, 1996) dalam Sudarmanto (2009;9) menyatakan bahwa untuk menjadi efektif, standar kinerja seharusnya dikaitkan dengan hasil yang diinginkan dari masing-masing pekerjaan. Lathams \& Wexley, 1981 (dalam Werther dan Davis, 1996) dalam Sudarmanto $(2009 ; 10)$ mengemukakan bahwa idealnya penilaian didasarkan pada kinerja aktual dari identifikasi elemen-elemen kritis melalu analisis pekerjaan.

Selanjutnya, menurut Gomez (2001) dalam Sudarmanto $(2009 ; 10)$ mengukur kinerja pegawai terkait dengan alat pengukuran kinerja yang digunakan. Terkait dengan alat pengukuran kinerja, secara garis besar diklasifikasikan dalam dua, yaitu; pertama, tipe penilaian yang dipersyaratkan; dengan penilaian relatif dan penilaian absolut. Penilaian relatif merupakan model penilaian dengan membandingkan kinerja seseorang dengan orang lain dalam jabatan yang sama. Model penilaian ini akan menghasilkan peringkatan kinerja antarpegawai dalam kelompok pekerjaan. Model penilaian absolut merupakan penilaian dengan menggunakan standar penilaian kinerja tertentu. Kedua, fokus pengukuran kinerja dengan 3 model, yaitu; penilaian kinerja berfokus sifat (trait), berfokus perilaku dan berfokus hasil.

Terkait dengan ukuran standar kinerja, David Devries, dkk (1981) dalam Sudarmanto $(2009 ; 10)$ menyatakan bahwa dalam melakukan pengukuran kinerja ada 3 (tiga) pendekatan, yaitu;

1. Pendekatan personality trait, yaitu dengan mengukur kepemimpinan, inisiatif, dan sikap.

2. Pendekatan perilaku, yaitu dengan mengukur, umpan balik, kemampuan presentasi, respons terhadap komplain pelanggan.

3. Pendekatan hasil, yaitu dengan mengukur; kemampuan produksi, kemampuan menyelesaikan produk sesuai jadwal, peningkatan produksi/penjualan. 
Menurut Dick Grote (1996) dalam Sudarmanto (2009;11) dalam bukunya The Complete Guide to Performance Appraisal menyatakan bahwa dalam pengukuran atau penilaian kinerja ada tiga pendekatan, yaitu:

1. Penilaian atau pengukuran kinerja berbasis pelaku.

2. Penilaian atau pengukuran kinerja berbasis perilaku.

3. Penilaian atau pengukuran kinerja hasil.

Dari berbagai pendapat ahli tersebut, standar pengukuran kinerja dapat dilakukan dengan mengukur 4 hal, yaitu:

a. Pengukuran kinerja dikaitkan dengan analisis pekerjaan, uraian pekerjaan.

b. Pengukuran kinerja dilakukan dengan mengukur sifat/karakter pribadi (traits).

c. Pengukuran kinerja dilakukan dengan mencapai hasil dari pekerjaan yang ingin dicapai.

d. Pengukuran kinerja dilakukan dengan mengukur perilaku atau tindakan-tindakan.

\section{Dimensi Kinerja atau Indikator Kinerja}

Dimensi atau indikator kinerja merupakan aspek-aspek yang menjadi ukuran dalam menilai kinerja. Ukuran-ukuran dijadikan tolok ukur dalam menilai kinerja. Dimensi ataupun ukuran kinerja sangat diperlukan karena akan bermanfaat baik bagi banyak pihak. Adapun survei literatur mengenai dimensi atau indikator yang menjadi ukuran kinerja adalah sebagai berikut:

John Miner (1988) dalam Sudarmanto $(2009 ; 11)$ mengemukakan 4 dimensi yang dapat dijadikan sebagai tolok ukur dalam menilai kinerja yaitu;

a. Kualitas, yaitu; tingkat kesalahan, kerusakan, kecermatan.

b. Kuantitas, yaitu jumlah pekerjaan yang dihasilkan.

c. Penggunaan waktu kerja, yaitu: tingkat ketidakhadiran, keterlambatan waktu kerja efektif/jam kerja hilang.

d. Kerja sama dengan orang lain dalam bekerja.

Dari empat dimensi kinerja diatas, dua hal terkait dengan aspek keluaran atau hasil pekerjaan; dan dua hal terkait aspek perilaku individu, yaitu penggunaan waktu dalam kerja (tingkat kepatuhan terhadap jam kerja, disiplin) dan kerja sama. Dari 4 dimensi kinerja tersebut cenderung mengukur kinerja pada level individu.

Bernardin (2001) dalam Sudarmanto $(2009 ; 12)$ menyampaikan ada 6 kriteria dasar atau dimensi untuk mengukur kinerja, yaitu;

a. Quality terkait dengan proses atau hasil mendekati sempurna/ideal dalam memenuhi maksud dan tujuan.

b. Quantity, terkait denan satuan jumlah atau kuantitas yang dihasilkan.

c. Timeliness, terkait dengan waktu yang diperlukan dalam menyelesaikan aktivitas atau menghasilkan produk.

d. Cost-effectiveness, terkait dengan tingkat penggunaan sumber-sumber organisasi (orang, uang, material, teknologi) dalam mendapatkan atau memperoleh hasil atau pengurangan pemborosan dalam penggunaan sumber-sumber organisasi.

e. Need for supervision, terkait dengan kemampuan individu dapat menyelesaikan pekerjaan atau fungsi-fungsi pekerjaan tanpa asistensi pimpinan atau intervensi pengawasan pimpinan.

f. Interpersonal impact, terkait dengan kemampuan individu dalam meningkatkan perasaan harga diri, keinginan baik, dan kerjasama di antara sesama pekerja dan anak buah.

Sedangkan Jerry Harbour (1997) dalam buku The Basics of Performance Measurement, merekomendasikan pengukuran kinerja dengan 6 aspek, yaitu:

1. Produktivitas; kemampuan dalam menghasilkan produk barang dan jasa. 
2. Kualitas; proses produksi barang dan jasa yang dihasilkan memenuhi standar kualitas.

3. Ketepatan Waktu (timeliness); waktu yang diperlukan dalam menghasilkan produk barang dan jasa tersebut.

4. Putaran Waktu; waktu yang dibutuhkan dalam setiap proses perubahan barang dan jasa tersebut kemudian sampai kepada pengguna/konsumen.

5. Penggunaan Sumber Daya; sumber daya diperlukan dalam menghasilkan produk barang dan jasa tersebut.

6. Biaya; biaya yang diperlukan.

\section{Kinerja Aparatur}

Kinerja bisa diketahui hanya jika individu atau kelompok individu tersebut mempunyai kriteria keberhasilan yang ditetapkan. Kriteria keberhasilan ini berupa tujuantujuan atau target-target tertentu yang hendak dicapai. Tanpa ada tujuan atau target, kinerja seseorang atau organisasi tidak dapat mungkin dapat diketahui karena tidak ada tolak ukurnya.

Widodo (Pasolong,2008:15) mengatakan bahwa kinerja adalah melakukan suatu kegiatan dan menyempurnakan sesuai dengan tanggung jawabnya dengan hasil seperti yang diharapkan.

"Performance" diterjemahkan dalam Bahasa Indonesia adalah kinerja, juga berarti prestasi kerja, pelaksanaan kerja, pencapaian kerja, atau hasil kerja/unjuk kerja/penampilan kerja (BKPP:9).

Secara etimologi aparatur berasal dari Bahasa Belanda "aparat", dalam Bahasa Inggris "apparatus" dan dalam bahasa birokrasi di Indonesia aparat berasal dari singkatan aparat dan struktur. Aparatur adalah orang-orang yang menjalankan roda pemerintahan. Aparatur pemerintah dapat digambarkan ibarat sebuah kapal maka aparatur adalah nahkoda kapal tersebut yang mesti harus tahu untuk apa kapal tersebut, bagaimana menjalankannya dan kemana tujuan kapal tersebut, maksudnya disini adalah aparatur pemerintah merupakan faktor yang amat sangat penting terhadap berjalannya roda pemerintahan.(ejournal.pin.or.id/site/wp)

\section{Administrasi Desa}

Sebelum menjelaskan konsep/pengertian administrasi pemerintahan terlebih dahulu perlu dijelaskan konsep "administrasi dan pemerintahan".

Menurut Siagian (1991:2):"Administrasi adalah keseluruhan proses pelaksanaan dari keputusan-keputusan yang telah diambil dan pelaksanaan itu pada umumnya dilakukan oleh dua orang manusia atau lebih untuk mencapai tujuan yang telah ditentukan sebelumnya".

Dewasa ini, peranan Pemerintah Desa sebagai struktur perantara, yakni sebagai penghubung antara masyarakat desa dengan pemerintah dan masyarakat di luar desa tetap dipertahankan, bahkan ditambah dengan peranan lainnya yaitu sebagai agen pembaharuan. Desa atau dengan nama lainnya yang sejenis menurut konstitusi memperoleh perhatian istimewa. Berbagai bentuk perubahan sosial yang terencana dengan nama pembangunan guna meningkatkan harkat dan martabat masyarakat desa diperkenalkan dan dijalankan melalui Pemerintah Desa.

Pemerintahan desa perlu terus dikembangkan sesuai dengan kemajuan masyarakat desa dan lingkungan sekitarnya. Dengan perkataan lain, perubahan sosial yang terjadi pada masyarakat desa karena adanya gerakan pembangunan desa perlu diimbangi pula dengan pengembangan kapasitas Pemerintahan Desa-nya, sehingga keinginan mempertahankan posisi tawar menawar dengan pihak luar desa yang relatif seimbang dapat terus dipertahankan. (Sadu Wasistiono, 2006: 4).

Lebih lanjut Sadu Wasistiono mengatakan bahwa tanpa adanya Pemerintahan Desa 
yang kuat, Desa dengan masyarakatnya hanya akan menjadi obyek permainan ekonomi maupun politik dari pihak-pihak luar desa yang relatif lebih kuat posisinya.

Langkah konkrit upaya pengembangan desa antara lain berupa lahirnya Undangundang Nomor 32 Tahun 2004 tentang Pemerintahan Daerah, yang merupakan pengganti berbagai peraturan perundangan mengenai pemerintahan desa. Salah satu tujuan dikeluarkannya Undang-undang Nomor 32 tahun 2004 adalah guna memodernisasikan pemerintahan desa agar mampu menjalankan tiga peranan utamanya, yaitu sebagai struktur perantara, sebagai pelayan masyarakat serta agen pembaharuan.

Sebagai konsekuensi negara hukum, perubahan format politik dan sistem pemerintahan harus ditindaklanjuti dengan perubahan peraturan perundang-undangan di bidang politik dan pemerintahan dengan dilakukannya perubahan peraturan pelaksanaan yang mengatur desa. Uniformitas yang diregulasi oleh UU No. 5 tahun 1979 selama dua dekade, direformasi melalui UU No. 22 tahun 1999 yang memberikan peluang kehidupan lebih demokrasi pada tataran struktur pemerintahan paling depan tersebut. Selanjutnya dengan diterapkannya UU No. 32 tahun 2004 tentang Pemerintahan Daerah diharapkan akan semakin menyempurnakan paradigma penyelenggaraan Pemerintahan Desa.

Pemerintah telah mengeluarkan Peraturan Pemerintah Nomor 72 Tahun 2005 tentang Desa sebagai pengganti Peraturan Pemerintah Nomor 76 Tahun 2001 tentang Pedoman Umum Pengaturan Mengenai Desa sebagai regulasi yang mengatur tentang Desa setelah setahun berlakunya UU No. 32 Tahun 2004.

Salah satu konsekuensi logis dari amanat Peraturan Pemerintah Nomor 72 Tahun 2005 tentang Desa, terutama aktivitas Pemerintah Desa sebagai pelayan masyarakat, maka diundangkanlah Peraturan Menteri Dalam Negeri Nomor 32 Tahun 2006 Tentang Pedoman Administrasi Desa yang membantu aparat dan perangkat Pemerintah Desa di dalam proses pencatatan data dan informasi berbagai urusan penyelenggaraan Pemerintahan Desa.

Secara etimologis, administrasi berasal dari bahasa latin ad+ministrare, suatu kata kerja yang berarti melayani, membantu, menunjang, atau memenuhi. Istilah ini berasal dari kata benda administratio dan kata sifat administratifus. Untuk Indonesia yang tepat digunakan istilah administrasi.

Rangkaian kegiatan yang digolongkan sebagai administrasi mencakup: (1) dilakukan oleh sekelompok orang (2 orang atau lebih); (2) berlangsung dalam suatu kerjasama; (3) dimaksudkan untuk mencapai tujuan tertentu yang telah ditetapkan. Ketiga faktor inilah yang merupakan tanda pengenal atau ciri khas dari administrasi yang apabila faktor-faktor tersebut disingkat adalah sekelompok orang, kerjasama, dan tujuan tertentu. Jadi bisa ditarik kesimpulan bahwa kerjasama adalah rangkaian perbuatan yang dilakukan bersama-sama secara teratur oleh lebih seorang yang menimbulkan akibat yang sebenarnya tidak akan terjadi apabila dilakukan oleh masing-masing seorang diri.

Administrasi diartikan sebagai suatu proses tata kerja penyelenggaraan atau dengan perkataan lain sebagai suatu proses kegiatan yang dilakukan secara teknis.

Administrasi adalah segenap rangkaian perbuatan sekelompok orang dalam suatu usaha kerja sama untuk mencapai suatu tujuan tertentu.

Administrasi adalah proses penyelenggaraan kegiatan untuk mewujudkan rencana/keputusan yang telah dibuat agar menjadi kenyataan, dengan cara mengatur kerja dan mengarahkan orang-orang yang melaksanakannya.

Administrasi juga dapat diartikan sebagai :

1. Suatu aktivitas yang terutama bersangkutan dengan cara untuk menyelenggarakan tujuan yang telah ditentukan semula;

2. Suatu proses lazim terdapat dalam segenap usaha bersama, baik usaha berskala besar maupun kecil-kecilan; 
3. Suatu proses pengorganisasian dan bimbingan orang-orang agar dapat melaksanakan suatu tujuan khusus;

4. Suatu proses penyelenggaraan dalam setiap usaha kerjasama sekelompok manusia untuk mencapai tujuan-tujuan tertentu. (Syafiie, Tanjung, Modeong, 1999:17)

Ada dua persepektif umum mengenai ruang lingkup dari administrasi. Perspektif yang pertama adalah perspektif makro yang meliputi proses penentuan tujuan, alokasi sumber daya, dan koordinasi kegiatan untuk pencapaian tujuan organisasi. Penekanan dari perspektif ini terutama pada aspek filosofis tentang apa tujuan dan makna kehidupan, apa tujuan yang kita inginkan dan bagaimana mencapainya, serta bagaimana seharusnya orang berperilaku. Perspektif selanjutnya adalah perspektif mikro, yang menerangkan perilaku administrasi sebagai sikap, pendekatan, persepsi, dan nilai-nilai yang dianut oleh para administrator. Stephen P. Robbins (1976) mengatakan bahwa perilaku administrasi dipengaruhi oleh sejarah organisasi, norma-norma pendidikan, dan pengalaman.

\section{Tugas dan Fungsi Pemerintah Desa}

Mengingat unit pemerintahan desa adalah bagian integral dari pemerintahan nasional, maka pembahasan tentang tugas dan fungsi pemerintah desa tidak terlepas dari tugas dan fungsi pemerintahan nasional seperti yang telah diuraikan dalam Undang-Undang Nomor 32 tahun 2004 pada pasal 127 tentang tugas pokok Kepala Desa yaitu: (a). Pelaksanaan kegiatan pemerintahan desa, (b). Pemberdayaan masyarakat, (c). Pelayanan masyarakat, (d). Penyelenggaraan ketentraman dan ketertiban umum, (e). Pemeliharaan prasarana dan fasilitas pelayanan umum.

Menurut Zainun (1990:3-5) terdapat empat kunci pokok tugas dan fungsi administrasi dan manajemen pemerintahan Indonesia yaitu : (a) Perumusan dan penetapan kebijakan umum,(b) Kepemimpinan, (c) Pengawasan, (d) Koordinasi.

Keempat fungsi administrasi dan manajemen ini akan diterapkan pada setiap tingkat pemerintahan yang ada dalam susunan pemerintahan negara Republik Indonesia. Berdasarkan tugas fungsi pemerintahan tersebut, berarti pemerintah desa sebagai bagian integral dari pemerintahan nasional juga menyelenggarakan fungsi-fungsi tersebut meskipun dalam ruang lingkup yang lebih sempit. Oleh unit pemerintahan desa seperti halnya pemerintah desa sebagai unit pemerintahan terendah mempunyai 3 fungsi pokok yaitu : (a).Pelayanan kepada masyarakat, (b). Fungsi operasional atau manajemen pembangunan, (c).Fungsi ketatausahaan atau registrasi (Sawe, 1996:99)

Keseluruhan tugas dan fungsi administrasi pemerintah desa tersebut, tidak akan terlaksana dengan baik, manakala tidak ditunjang dari aparatnya dengan melaksanakan sebaik-baiknya apa yang menjadi tanggung jawab masing-masing aparat.

Menyadari betapa pentingnya tugas administrasi pemerintahan desa, maka yang menjadi keharusan bagi Kepala Desa dan aparatnya adalah berusaha untuk mengembangkan kecakapan dan keterampilan mengelola organisasi pemerintahan desa termasuk kemampuannya untuk melaksanakan tugas-tugas dibidang pemerintahan, pembangunan dan kemasyarakatan.

Selanjutnya menurut Beratha (1992:37) mengemukakan bahwa tugas pemerintah desa termasuk dalam menjalankan administrasi adalah:

1. Tugas bidang pemerintahan

a. Registrasi

Registrasi dilakukan dalam berbagai buku register mengenai berbagai hal dan peristiwa yang menyangkut kehidupan tindakan masyarakat berdasarkan laporan yang diperoleh melalui sub pelayanan umum dari masyarakat yang berkepentingan. 
b. Tugas-tugas umum meliputi: menerima dan melaksanakan instruksi-instruksi dan petunjuk-petunjuk dari pemerintah kecamatan dan pemerintah kabupaten mengenai pemerintahan, tugas-tugas teknis; ketertiban, kesejahteraan dan keamanan,

c. Membuat laporan periodik mengenai keadaan dan perubahan penduduk, keamanan serta sosial ekonomi.

d. Melaksanakan hal-hal yang sudah menjadi keputusan ditingkat desa.

e. Melaksanakan kerjasama dengan instansi ditingkat desa dan menyelesaikan permasalahan yang berhubungan dengan tanah,

2. Tugas bidang pelayanan kepada masyarakat.

a. Pemberian bermacam-macam izin, seperti izin tempat tinggal, izin meninggalkan desa, izin usaha dan izin pendirian bangunan.

b. Memberikan macam-macam keterangan seperti: bukti diri, keterangan catatan kepolisian dan sebagainya.

3. Tugas bidang ketatausahaan.

Dokumentasi data, keadaan wilayah, laporan keuangan dan lain-lain. Sementara itu, menurut instruksi Menteri Dalam Negeri Nomor 21 Tahun 1992, pada pasal (2) ditegaskan bahwa "desa mempunyai tugas melakukan penyelenggaraan pemerintahan pembangunan dan kemasyarakatan dalam rangka penyelenggaraan urusan pemerintahan umum dan urusan pemerintahan daerah dan wilayahnya. Untuk menyelenggarakan tugas tersebut (pasal 2) Desa mempunyai fungsi (pasal 3), yaitu:

a. Melakukan koordinasi terhadap jalannya pemerintahan desa, pelaksanaan pembangunan dan pembinaan kemasyarakatan.

b. Melakukan tugas dibidang pembangunan dan pembinaan kemasyarakatan yang menjadi tanggung jawabnya.

c. Melakukan usaha dalam rangka peningkatan partisipasi dan swadaya gotongroyong masyarakat.

d. Melakukan kegiatan dalam rangka pembinaan Ketentraman dan ketertiban wilayah.

e. Melakukan fungsi-fungsi lain yang dilimpahkan kepada pemerintah.

Pelaksanaan tugas dan fungsi desa tersebut, selanjutnya dijabarkan menjadi tugas dan fungsi masing-msing unsur aparat baik Kepala Desa maupun aparatnya yang terdiri dari : Sekretaris, Kepala-Kepala Urusan, Kepala-Kepala Lingkungan.

\section{Pengelolaan Administrasi Desa}

Kata "Pengelolaan" dapat disamakan dengan manajemen, yang berarti pula pengaturan atau pengurusan (Suharsimi Arikunto, 1993:31). Banyak orang mengartikan manajemen sebagai pengaturan, pengelolaan, dan pengadministrasian, dan memang itulah pengertian yang populer saat ini. Pengelolaan diartikan sebagai suatu rangkaian pekerjaan atau usaha yang dilakukan oleh sekelompok orang untuk melakukan serangkaian kerja dalam mencapai tujuan tertentu.

Griffin (1990:6) mendefinisikan manajemen sebagai berikut: "Management is the process of planning and decision making, organizing, leading and controlling and organization human, financial, physical and information resources to archieve organizational goals in an efficient and effective manner".

Dikatakan manajemen adalah suatu proses perencanaan dan pengambilan keputusan, pengorganisasian, memimpin dan pengendalian organisasi manusia, keuangan, fisik, dan informasi sumber daya untuk mencapai tujuan organisasi secara efisiensi dan efektif. Nanang Fattah, (2004:1) berpendapat bahwa dalam proses manajemen terlibat fungsi-fungsi 
pokok yang ditampilkan oleh seorang manajer atau pimpinan, yaitu perencanaan (planning), pengorganisasian (organizing), pemimpin (leading), dan pengawasan (controlling). Oleh karena itu, manajemen diartikan sebagai proses merencanakan, mengorganising, memimpin, dan mengendalikan upaya organisasi dengan segala aspeknya agar tujuan organisasi tercapai secara efektif dan efisien. Pengertian manajemen telah banyak dibahas para ahli yang antara satu dengan yang lain saling melengkapi. Stoner yang dikutip oleh Handoko menyatakan bahwa manajemen merupakan proses perencanaan, pengorganisasian, pengarahan, dan pengawasan, usaha-usaha para anggota organsasi dan pengguna sumber daya organisasi lainnya untuk mencapai tujuan organisasi yang telah ditetapkan. Stoner menekankan bahwa manajemen dititik beratkan pada proses dan sistem. Oleh karena itu, apabila dalam sistem dan proses perencanaan, pengorganisasian, pengarahan, penganggaran, dan sistem pengawasan tidak baik, proses manajemen secara keseluruhan tidak lancar sehingga proses pencapaian tujuan akan terganggu atau mengalami kegagalan (Shyhabuddin Qalyubi, 2007:271).

Berdasarkan definisi manajemen diatas secara garis besar tahap-tahap dalam melakukan manajemen meliputi melakukan perencanaan, pengorganisasian, pelaksanaan, dan pengawasan. Perencanaan merupakan proses dasar dari suatu kegiatan pengelolaan dan merupakan syarat mutlak dalam suatu kegiatan pengelolaan. Kemudian pengorganisasian berkaitan dengan pelaksanaan perencanaan yang telah ditetapkan. Sementara itu pengarahan diperlukan agar menghasilkan sesuatu yang diharapkan dan pengawasan yang melekat. Dengan evaluasi, dapat menjadi proses monitoring aktivitas untuk menentukan apakah individu atau kelompok memperoleh dan menggunakan sumber-sumbernya secara efektif dan efisien untuk mencapai tujuan.

\section{Fungsi Pengelolaan}

Berdasarkan fungsi manajemen (pengelolaan) diatas secara garis besar dapat disampaikan bahwa tahap-tahap dalam melakukan manajemen meliputi: perencanaan, pengorganisasian, pelaksanaan, dan pengawasan. Fungsi-fungsi manajemen tersebut bersifat universal, di mana saja dan dalam organisasi apa saja. Namun, semuanya tergantung pada tipe organisasi, kebudayaan, dan anggotanya. Pada penelitian ini, peneliti cenderung berpedoman pada pendapat Terry dalam The Liang Gie (2000:21), yang menyatakan bahwa kegiatan manajemen, meliputi: perencanaan (planning), pengorganisasian (organizing), pengarahan (actuating), dan pengawasan (controlling).

a. Perencanaan (Planning), batasan pengertian perencanaan bermacam-macam sesuai dengan pendapat para ahli manajemen. Perencanaan diartikan sebagai perhitungan dan penentuan tentang apa yang akan dijalankan dalam rangka mencapai tujuan tertentu, dimana menyangkut tempat, oleh siapa pelaku itu atau pelaksana dan bagaimana tata cara mencapai itu.

b. Pengorganisasian (Organizing), pengorganisasian merupakan pengelompokan kegiatan-kegiatan penugasan kegiatan-kegiatan penyediaan keperluan, wewenang untuk melaksanakan kegiatannya. Dalam suatu organisasi dituntut adanya kerja sama antara dua orang atau lebih untuk mencapai suatu tujuan secara efektif dan efisien. Organisasi merupakan suatu proses untuk merancang struktur formal, pengelompokkan dan mengatur serta membagi tugas-tugas atau pekerjaan diantara para anggota agar tujuan organisasi dapat tercapai.

c. Pengarahan (Actuating), pengarahan adalah keinginan untuk membuat orang lain mengikuti keinginannya dengan menggunakan kekuatan pribadi atau kekuasaan jabatan secara efektif dan pada tempatnya demi kepentingan jangka panjang perusahaan. Termasuk didalamnya memberitahukan orang lain apa yang harus dilakukan dengan nada yang bervariasi mulai dari nada tegas sampai meminta atau 
bahkan mengancam.

d. Pengawasan (Controlling), pengawasan adalah kegiatan membandingkan atau mengukur yang sedang atau sudah dilaksanakan dengan kriteria, norma-norma standar atau rencana-rencana yang sudah ditetapkan sebelumnya (Sutarno NS, 2004:128)

\section{Administrasi Desa}

Administrasi Desa menurut Peraturan Menteri Dalam Negeri Nomor 32 Tahun 2006 adalah keseluruhan proses kegiatan pencatatan data dan informasi mengenai penyelenggaraan Pemerintahan Desa pada Buku Administrasi Desa.

Jenis dan bentuk Administrasi Desa menurut Peraturan Menteri Dalam Negeri Nomor 32 Tahun 2006:

a. Administrasi Umum adalah kegiatan pencatatan data dan informasi mengenai kegiatan Pemerintahan Desa pada Buku Administrasi Umum, terdiri dari:

1. Buku Data Peraturan Desa; berisi himpunan peraturan-peraturan yang dicatat berdasarkan perihal/tentang, waktu penetapan, tempat penetapan.

2. Buku Data Keputusan Kepala Desa; berisi himpunan keputusan Kepala Desa yang dicatat berdasarkan perihal/tentang, waktu penetapan, tempat penetapan.

3. Buku Data Inventaris Desa; berisi tentang kekayaan pemerintah desa baik benda bergerak maupun benda tidak bergerak.

4. Buku Data Aparat Pemerintah Desa; berisi tentang data jumlah dan profil aparat desa secara lengkap.

5. Buku Data Tanah Milik Desa/Tanah Kas Desa; berisi tentang keterangan jumlah, ukuran/luas tanah yang dimiliki oleh pemerintah desa.

6. Buku Data Tanah di Desa; berisi tentang keterangan jumlah, ukuran/luas tanah yang dimiliki oleh masyarakat desa secara pribadi.

7. Buku Agenda; berisi tentang rencana-rencana pemerintahan desa pada waktu yang akan datang.

8. Buku Ekspedisi; berisi tentang catatan tanggal dan perihal surat masuk dan surat keluar.

b. Administrasi Penduduk adalah kegiatan pencatatan data dan informasi mengenai penduduk dan mutasi penduduk pada Buku Administrasi Penduduk, terdiri dari:

1. Buku Data Induk Penduduk Desa; berisi tentang jumlah dan profil kependudukan secara umum.

2. Buku Data Mutasi Penduduk Desa; berisi tentang data penduduk yang pindah maupun data penduduk yang datang.

3. Buku Data Rekapitulasi Jumlah Penduduk Akhir Bulan; berisi tentang data jumlah dan profil penduduk setiap akhir bulan.

4. Buku Data Penduduk Sementara: berisi tentang jumlah dan profil penduduk musiman yang tinggal di desa.

c. Administrasi Keuangan adalah kegiatan pencatatan data dan informasi mengenai pengelolaan keuangan desa pada Buku Administrasi Keuangan, terdiri dari:

1. Buku Anggaran Penerimaan; berisi tentang sumber dan jenis pendapatan kas desa per periode anggaran.

2. Buku Anggaran Pengeluaran Rutin; berisi tentang catatan pengeluaran rutin untuk pembiayaan rutin seperti gaji aparat desa, pembayaran listrik dan PAM kantor desa, dan lain-lain.

3. Buku Anggaran Pengeluaran Pembangunan; berisi tentang catatan pengeluaran untuk kegiatan pembangunan desa baik fisik dan non fisik.

4. Buku Kas Umum; berisi catatan pemasukan dan pengeluaran secara umum. 
5. Buku Kas Pembantu Penerimaan; berisi catatan pemasukan kas desa yang bersumber dari pendapatan lain-lain yang syah.

6. Buku Kas Pembantu Pengeluaran Rutin; berisi catatan pengeluaran kas desa yang diperuntukkan keperluan rutin desa.

7. Buku Kas Pembantu Pengeluaran Pembangunan; berisi catatan pengeluaran pembangunan yang secara umum/kasar.

d. Administrasi Pembangunan adalah kegiatan pencatatan data dan informasi pembangunan yang akan, sedang, dan telah dilaksanakan pada Buku Administrasi Pembangunan, terdiri dari:

1. Buku Rencana Pembangunan; berisi catatan rencana-rencana pembangunan secara rinci (jenis pembangunan, waktu, biaya, dll)

2. Buku Kegiatan Pembangunan; berisi catatan pelaksanaan pembangunan secara rinci.

3. Buku Inventaris Proyek; berisi tentang data jumlah dan jenis proyek yang pernah dijalankan di desa.

4. Buku Kader-Kader Pembangunan/Pemberdayaan Masyarakat; berisi te tentang data jumlah dan profil kader pembangunan/pemberdayaan masyarakat desa.

e. Administrasi Badan Permusyawaratan Desa (BPD) atau yang disebut dengan BPD adalah kegiatan pencatatan data dan informasi mengenai BPD, terdiri dari:

1. Buku Data Anggota BPD; berisi data jumlah dan profil anggota BPD.

2. Buku Data Keputusan BPD; berisi catatan Keputusan BPD (Tanggal, Perihal, Tempat, dll).

3. Buku Data Kegiatan BPD; berisi catatan kegiatan yang dilakukan oleh anggota BPD dalam satu periode.

4. Buku Agenda BPD; berisi rencana-rencana kegiatan BPD yang akan dilaksanakan pada masa yang akan datang.

5. Buku Ekspedisi BPD; berisi catatan surat keluar dan surat masuk dalam rangka pelaksanaan tugas dan fungsi BPD.

Rangkaian kegiatan yang digolongkan sebagai administrasi mencakup: (1) dilakukan oleh sekelompok orang (2 orang atau lebih); (2) berlangsung dalam suatu kerjasama; (3) dimaksudkan untuk mencapai tujuan tertentu yang telah ditetapkan. Ketiga faktor inilah yang merupakan tanda pengenal atau ciri khas dari administrasi yang apabila faktor-faktor tersebut disingkat adalah sekelompok orang, kerjasama, dan tujuan tertentu. Jadi bisa ditarik kesimpulan bahwa kerjasama adalah rangkaian perbuatan yang dilakukan bersama-sama secara teratur oleh lebih seorang yang menimbulkan akibat yang sebenarnya tidak akan terjadi apabila dilakukan oleh masing-masing seorang diri.

Administrasi adalah proses penyelenggaraan kegiatan untuk mewujudkan rencana/keputusan yang telah dibuat agar menjadi kenyataan, dengan cara mengatur kerja dan mengarahkan orang-orang yang melaksanakannya.

Administrasi juga dapat diartikan sebagai:

1. Suatu aktivitas yang terutama bersangkutan dengan cara untuk menyelenggarakan tujuan yang telah ditentukan semula;

2. Suatu proses lazim terdapat dalam segenap usaha bersama, baik usaha berskala besar maupun kecil-kecilan;

3. Suatu proses pengorganisasian dan bimbingan orang-orang agar dapat melaksanakan suatu tujuan khusus;

4. Suatu proses penyelenggaraan dalam setiap usaha kerjasama sekelompok manusia untuk mencapai tujuan-tujuan tertentu. (Syafiie, Tanjung, Modeong, 1999:17).

Berdasarkan pengertian tersebut dan apabila dikaitkan dengan aktifitas ditingkat desa, maka berbicara tentang administrasi desa berarti yang dimaksud dengan "administrasi" 
adalah rangkaian kegiatan yang dilakukan oleh penyelenggara pemerintahan desa untuk mencapai tujuan pemerintahan, seperti antara lain, baik dalam menggerakkan partisipasi dalam pembangunan dan terwujudnya Demokrasi Pancasila secara nyata guna meningkatkan taraf hidup masyarakat.

Mengacu pada pengertian diatas berarti konsep administrasi terbagi dalam dua pengertian yaitu administrasi dalam arti sempit dan administrasi dalam arti luas. Administrasi dalam arti luas berarti segenap proses kegiatan untuk mencapai tujuan sedangkan administrasi dalam arti sempit adalah segenap penyelenggaraan kegiatan tulis menulis, Surat menyurat, beserta penyimpanan, pengurusan masalah-masalah dan segala pencatatannya dilaksanakan oleh aparat dalam arti pencapaian tujuan (Widjaja,1992:88).

Selanjutnya konsep/pengertian pemerintah dan pemerintahan dalam kajian sistem pemerintahan Indonesia, pemerintah dibedakan dengan istilah pemerintahan. Menurut Saparin (1996:21) untuk membedakan pengertian kedua konsep tersebut, maka perlu diterangkan secara etimologis, yaitu:

a. Pemerintah adalah kata nama subjek yang berdiri sendiri, contoh Pemerintah Daerah.

b. Pemerintah adalah kata jadian yang disebabkan karena subjeknya mendapat akhiran "an" yang artinya pemerintah sebagai subjek melakukan tugas-tugas atau kegiatan, dimana cara melakukan kegiatan itu disebut pemerintahan.

Ada dua persepektif umum mengenai ruang lingkup dari administrasi. Perspektif yang pertama adalah perspektif makro yang meliputi proses penentuan tujuan, alokasi sumber daya, dan koordinasi kegiatan untuk pencapaian tujuan organisasi. Penekanan dari perspektif ini terutama pada aspek filosofis tentang apa tujuan dan makna kehidupan, apa tujuan yang kita inginkan dan bagaimana mencapainya, serta bagaimana seharusnya orang berperilaku. Perspektif selanjutnya adalah perspektif mikro, yang menerangkan perilaku administrasi sebagai sikap, pendekatan, persepsi, dan nilai-nilai yang dianut oleh para administrator. Stephen P. Robbins (1976) mengatakan bahwa perilaku administrasi dipengaruhi oleh sejarah organisasi, norma-norma pendidikan, dan pengalaman.

Dari uraian diatas nampak istilah pemerintah menunjuk kepada aparat yaitu para pelaksana pemerintahan, sedang istilah pemerintahan menunjuk pada aktifitas atau kegiatan yang dilakukan oleh pemerintah. Hal ini berarti "Pemerintahan" adalah keseluruhan tindakan atau kegiatan aparat pemerintah dalam menjalankan tugas dan fungsinya.

Selanjutnya dalam penyelenggaraan pemerintah desa pemerintah telah menerbitkan aturan terbaru dalam bentuk undang-undang yakni Undang-Undang Republik Indonesia Nomor 16 Tahun 2014 tentang Desa yang mana dalam salah satu batang tubuhnya yakni Bab V tentang Penyelenggaraan Desa, Pasal 24 poin (b) tertib penyelenggaraan pemerintahan, poin (g) akuntabilitas. Dengan demikian dapat dimaknai bahwa undang-undang terbaru tentang desa juga menekankan penyelenggaraan pemerintahan desa yang tertib dan juga akuntabilitas pemerintahan desa. Salah satu bentuk akuntabilitas itu adalah terwujud penyelenggaraan administrasi desa tertib, baik, dan berkualitas.

\section{METODE PENELITIAN}

Jenis penelitian yang dipilih adalah penelitian deskriptif-kualitatif. Dipilihnya jenis penelitian ini dengan mempertimbangkan bahwa peneliti akan dapat menggali informasi secara lebih dalam tentang pengelolaan administrasi desa, jika informasi disampaikan oleh para narasumber secara deskriptif. Diharapkan dengan cara ini para narasumber dapat mendeskripsikan data dan informasi yang dibutuhkan dalam penelitian. Untuk mempertajam kajian penelitian, digunakanlah pendekatan studi kasus intrinsik. Dengan cara ini diharapkan peneliti mendapatkan gambaran karakteristik locus penelitian, yang membedakan dengan penelitian-penelitian terdahulu. 


\section{Lokasi Penelitian}

Lokasi penelitian dipilih di Desa Tumbang Kaman, Kecamatan Sanaman Mantikei, Kabupaten Katingan. Alasan mendasar dipilihnya lokasi ini adalah tersedianya Pemerintahan Desa yang sudah berlangsung cukup lama semenjak terjadi pemekaran kecamatan dan pemekaran desa. Alasan lain adalah Pemerintah Desa Tumbang Kaman telah memiliki struktur pemerintahan yang lengkap baik Kepala Desa (Kades) maupun Badan Permusyawaratan Desa (BPD), sehingga layak untuk dilakukan kajian terhadap kapasitas pemerintah desa dalam pengelolaan administrasi desa.

\section{Fokus Penelitian}

Penelitian ini mengambil fokus pada kinerja aparatur pemerintah desa yang meliputi:

a. Kualitas pengelolaan administrasi desa;

b. Kuantitas pengelolaan administrasi desa;

c. Penggunaan waktu kerja dalam pengelolaan administrasi desa;

d. Kerjasama dalam pengelolaan administrasi desa.

\section{Sumber Data}

Berdasarkan sumber pengambilan data dibedakan menjadi 2 (dua) yaitu :

1. Data primer diperoleh peneliti melalui pengamatan atau observasi secara langsung yang didukung oleh wawancara terhadap informasi atau pihak-pihak yang bersangkutan (narasumber). Pencatatan sumber data utama melalui pengamatan atau observasi dan wawancara merupakan hasil usaha gabungan dari kegiatan melihat, mendengar, dan bertanya yang dilakukan secara sadar, terarah, dan senantiasa bertujuan memperoleh informasi yang diperlukan. Adapun narasumbernya meliputi Kepala Desa (Kades) Tumbang Kaman, Sekretaris Desa (Sekdes), Ketua Badan Permusyawaratan Desa (BPD), Pak Yoyo (Masyarakat), Pak Wawan (Masyarakat), Pak Ardi (Masyarakat).

2. Data Sekunder dalam penelitian ini juga diperlukan, berfungsi sebagai pelengkap atau pendukung data primer. Data ini bersumber dari buku-buku literatur, peraturan perundangan dan dokumen-dokumen resmi yang berhubungan dengan pengelolaan administrasi desa di Tumbang Kaman.

\section{Instrumen Penelitian}

Penelitian dapat dilakukan apabila telah tersedia instrumen yang digunakan untuk mengumpulkan data. Prosedur yang ditempuh dalam pengadaan instrumen yang baik, antara lain : 1) perencanaan yang meliputi perumusan tujuan dan menentukan fokus penelitian; 2) sampel penelitian; 3) lokasi penelitian; 4) pelaksana; 5) biaya dan waktu; 6) data.

Instrumen utama dalam penelitian ini adalah peneliti sendiri yang mengadakan pengamatan-pengamatan dan wawancara, melakukan analisis data dan mendeskripsikan hasil penelitiannya. Dalam mengumpulkan data, peneliti dibantu dengan pedoman wawancara (Interview Guide), alat tulis-menulis, kamera foto, dan tape recorder.

\section{Teknik Pengumpulan Data}

Guna memperoleh data dan informasi yang akurat mengenai permasalahan yang diteliti, maka digunakan beberapa teknik pengumpulan data (Sugiyono, 2013:225) yaitu :

- Observasi

Yaitu cara pengumpulan data dengan pengamatan secara langsung terhadap obyek penelitian, sehingga diperoleh gambaran dari data dan fakta mengenai permasalahan yang diteliti. Hasil observasi ini dapat mempermudah dalam menjelaskan keterkaitan dari fenomena-fenomena yang ada. 
- Wawancara

Wawancara adalah pertemuan dua orang untuk bertukar informasi dan ide melalui tanya jawab, sehingga dapat dikonstruksikan makna dalam suatu topik tertentu.

- Dokumentasi

Dokumentasi adalah pengumpulan data dengan cara studi kepustakaan, meneliti dokumen-dokumen, catatan-catatan, serta arsip-arsip yang berkaitan dengan sasaran penelitian.

\section{Teknik Analisis Data Model Miles and Huberman}

Analisis data dalam penelitian kualitatif, dilakukan pada saat pengumpulan data berlangsung, dan setelah selesai pengumpulan data dalam periode tertentu. Pada saat wawancara, peneliti sudah melakukan analisis terhadap jawaban yang diwawancarai. Bila jawaban yang diwawancarai setelah dianalisis terasa belum memuaskan, maka peneliti akan melanjutkan pertanyaan lagi, sampai tahap tertentu, diperoleh data yang dianggap kredibel. Miles and Huberman (1994) dalam Sugiyono (2013:246), mengemukakan bahwa aktivitas dalam analisis data kualitatif dilakukan secara interaktif dan berlangsung secara terus menerus sampai tuntas, sehingga datanya sudah jenuh. Aktivitas dalam analisis data, yaitu data reduction, data display, dan conclusion drawing/verification.

a. Data Reduction (Reduksi Data)

Data yang diperoleh dari lapangan jumlahnya cukup banyak, untuk itu maka perlu dicatat secara teliti dan rinci. Seperti telah dikemukakan, semakin lama peneliti ke lapangan, maka jumlah data akan semakin banyak, kompleks dan rumit. Untuk itu perlu segera dilakukan analisis data melalui reduksi data. Mereduksi data berarti merangkum, memilih hal-hal yang pokok, memfokuskan pada hal-hal yang penting, dicari tema dan polanya. Dengan demikian data telah direduksi akan memberikan gambaran yang lebih jelas, dan mempermudah peneliti untuk melakuka pengumpulan data selanjutnya, dan mencarinya bila diperlukan. Reduksi data dapat dibantu dengan peralatan elektronik seperti komputer mini, dengan memberikan kode pada aspek-aspek tertentu.

b. Data Display (Penyajian Data)

Setelah data direduksi, maka langkah selanjutnya adalah mendisplaykan data. Kalau dalam penelitian kuantitatif penyajian data ini dapat dilakukan dalam bentuk tabel, grafik, phie card, pictogram, dan sejenisnya. Melalui penyajian data tersebut, maka data terorganisasikan, tersusun dalam pola hubungan, sehingga akan semakin mudah dipahami.

Dalam penelitian kualitatif, penyajian data bisa dilakukan dalam bentuk uraian singkat, bagan, hubungan antar kategori, flowchart dan sejenisnya. Dalam hal ini Miles and Huberman (1984) menyatakan "the most frequent form of display data for qualitative research data in the past has been narrative text". Yang paling sering digunakan untuk menyajikan data dalam penelitian kualitatif adalah dengan teks yang bersifat naratif.

c. Conclusion Drawing/Verification

Langkah ketiga dalam analisis data kualitatif menurut Miles and Huberman adalah penarikan kesimpulan dan verifikasi. Kesimpulan awal yang dikemukakan masih bersifat sementara, dan akan berubah bila tidak ditemukan bukti-bukti yang kuat mendukung pada tahap pengumpulan data berikutnya. Tetapi apabila kesimpulan yang dikemukakan pada tahap awal, didukung oleh bukti-bukti yang valid dan konsisten saat peneliti kembali ke lapangan mengumpulkan data, maka kesimpulan yang dikemukakan merupakan kesimpulan yang kredibel. Dengan demikian kesimpulan dalam penelitian kualitatif mungkin dapat menjawab rumusan masalah yang dirumuskan sejak awal, tetapi mungkin juga tidak, karena seperti telah dikemukakan bahwa masalah dan rumusan 
masalah dalam penelitian kualitatif masih bersifat sementara dan akan berkembang setelah peneliti berada di lapangan.

\section{HASIL DAN PEMBAHASAN}

\section{Kinerja}

Secara konsep kinerja dianggap sebagai pergeseran dari produktivitas. Namun dalam perkembangannya untuk sebuah organisasi memiliki kinerja yang baik atau kurang baik, tidak dapat ditinjau dari aspek produktivitas saja. Akan tetapi harus dilihat dari aspek-aspek lainnya yang lebih luas dan komprehensif.

Kinerja yang melekat pada Pemerintah Desa Tumbang Kaman tentu tidak dapat hanya dilihat dari produktivitas saja. Ada aspek-aspek lain yang menjadi pertimbangan seperti aspek kualitas, aspek kuantitas, aspek penggunaan waktu kerja, dan aspek kerjasama.

Berdasarkan hasil-hasil penelitian sebagaimana diuraikan diatas, Pemerintah Desa Tumbang Kaman lebih memiliki kinerja yang baik dalam hal produktivitas. Hal tersebut ditunjukkan dalam kuantitas/jumlah pelayanan yang dapat disampaikan/diberikan kepada masyarakat. Pengamatan dilapangan menunjukkan masyarakat dilayani dengan baik tanpa mengenal tempat dan jam kerja. Di rumah Kades masyarakat juga tetap dilayani. Diluar jam kerja masyarakat juga tetap dilayani. Dengan demikian Pemerintah Desa Tumbang Kaman telah berupaya untuk menunjukkan kinerja yang baik.

Terkait dengan konsep kinerja, Rummler dan Brache (1995) dalam Sudarmanto (2009:7) mengemukakan ada 3 (tiga) level kinerja: kinerja organisasi, kinerja proses, dan kinerja individu/pekerjaan. Dari hasil penelitian tersebut diatas dan pengamatan dilapangan menunjukkan bahwa Pemerintah Desa Tumbang Kaman baru mampu menunjukkan kinerja individu/pekerjaan. Karena fakta menunjukkan bahwa peran Kepala Desa sangat dominan dalam pengelolaan administrasi desa. Sedangkan sekretaris desa dan staf belum mampu menunjukkan level kinerja yang sama dibandingkan dengan Kepala Desa. Meski mendapat gelar juara lomba desa, hal tersebut belum dapat dijadikan tolok ukur keberhasilan Pemeirntah Desa Tumbang Kaman sebagai level kinerja organisasi.

Bila ditinjau dari aspek kinerja sebagai perilaku menurut Murphy (1990) dalam Sudarmanto $(2009 ; 8)$, maka sebenarnya seluruh perangkat desa di Tumbang Kaman telah memiliki perilaku yang baik yang menunjang terhadap pencapaian kinerja yang baik. Akan tetapi hal tersebut terkendala dari kemampuan dan ketrampilan individu dalam pengelolan administrasi, khususnya dalam hal penggunaan komputer.

\section{Pengukuran Kinerja}

Untuk dapat mengukur kinerja organisasi secara efektif seharusnya ada yang namanya "standar kinerja". Hal ini bisa menjadi patokan/acuan dalam menilai kinerja organisasi.

Berdasarkan hasil-hasil penelitian tersebut diatas dan pengamatan dilapangan tidak ditemukan standar kinerja yang menjadi acuan perangkat desa untuk melaksanakan tugas pokok dan fungsinya. Meski diketahui bahwa pemerintah telah mengatur dalam undangundangan tentang desa, Peraturan Pemerintah (PP) yang mengatur tentang penyelenggaraan pemerintah desa, peraturan menteri dalam negeri tentang pedoma administrasi desa, keputusan menteri tentang standar pelayanan publik, dan lain sebagainya. Akan tetapi semua aturan tersebut belum menjadi standar kinerja bagi Pemerintah Desa Tumbang Kaman.

Banyak faktor yang menyebabkan standar kinerja belum dijadikan patokan kerja bagi Pemerinta Desa Tumbang Kaman. Paling sederhana adalah ketidaktahuan mereka tentang peraturan perundangan yang mengatur tentang penyelenggaraan pemerintah desa. Kalaupun mereka mengetahui tentang berbagai peraturan perundangan tersebut, belum tentu mampu memahaminya. Kalaupun mereka memahaminya belum tentu mereka mampu 
melaksanakannya karena latarbelakang situasi dan kondisi yang berbeda. Sebagai contoh sederhana adalah persoalan jam kerja. Aturan pemerintah sudah jelas bahwa jam kerja dan pelayanan kepada masyarakat itu berkisar 7-8 jam kerja sehari. Dan itu harus dilaksanakan pada pagi hari hingga siang hari. Namun faktanya, masyarakat cukup banyak yang minta dilayani pada sore hari dan malam hari. Hal ini disebabkan pada pagi hari mereka banyak bekerja ke ladang yang jaraknya cukup jauh sehingga tidak memungkinkan untuk pulang pergi.

Selanjutnya, menurut Gomez (2001) dalam Sudarmanto $(2009 ; 10)$ ada 2 tipe/model penilaian kinerja: penilaian relatif dan penilaian absolut. Dari 2 tipe/model penilaian kerja tersebut, Pemerintah Desa Tumbang Kaman relatif lebih baik jika dibandingkan dengan pemerintah desa lainnya di Kecamatan Sanaman Mantikei, karena memiliki Kepala Desa yang terampil dalam mengelola administrasi desa. Desa lain Kepala Desa-nya kurang terampil dalam mengelola administrasi desa. Menurut tipe/model penilaian absolut berdasarkan indikator yang jelas, Pemerintah Desa Tumbang Kaman terbukti memiliki kinerja yang baik ditunjukkan sebagai juara I lomba desa tingkat Kecamatan Sanaman Mantikei.

Terkait dengan ukuran standar kinerja, David Devries, dkk (1981) dalam Sudarmanto $(2009 ; 10)$ menyatakan bahwa dalam melakukan pengukuran kinerja ada 3 (tiga) pendekatan, yaitu: pendekatan personality trait, pendekatan perilaku, dan pendekatan hasil. Ketiga pendekatan tersebut telah diterapkan dalam penelitian ini untuk mengukur kinerja aparat Pemerintah Desa Tumbang Kaman dalam pengelolaan administrasi desa. Hasilnya menunjukkan bahwa kepemimpinan Kepala Desa Tumbang Kaman telah mampu mendorong aparat desa untuk berperilaku yang baik dalam mengelola administrasi desa dan melayani masyarakat. Meski secara kualitas pengelolaan administrasi desa di Tumbang Kaman masih harus terus ditingkatkan. Kemampuan mengelola administrasi desa, seharusnya tersebar secara merata kepada seluruh perangkat desa. Tidak hanya bertumpu pada Kepala Desa Tumbang Kaman saja.

\section{Dimensi Kinerja atau Indikator Kinerja}

Dimensi kinerja atau indikator kinerja menurut John Miner (1988) dalam Sudarmanto $(2009 ; 11)$ ada 4 dimensi: kualitas, kuantitas, penggunaan waktu kerja dan kerjasama. Keempat aspek tersebut menjadi fokus dalam penelitian ini dan hasilnya telah diuraikan diatas. Kesemuanya menunjukkan hasil yang baik jika hanya diukur dari keberhasilan Pemerintah Desa Tumbang Kaman sebagai juara lomba desa. Akan tetapi jika ditinjau lebih dalam tentu masih harus diperbaiki lagi. Dari aspek kualitas, diharapkan tingkat kesalahan pengurusan administrasi harus terus ditekan. Dari aspek kuantitas, memang tidak menjadi masalah karena hampir seluruh kebutuhan layanan terhadap masyarakat dapat dilayani, akan tetapi untuk standar internal pengelolaan administrasi desa sebagaimana diatur dalam Permendagri No. 32 Tahun 2006 tentang Pedoman Administrasi Desa, masih banyak buku /item administrasi yang harus dipenuhi. Dari aspek penggunaan waktu kerja, seharusnya lebih mengacu pada aturan pemerintah mengenai jam kerja yakni pukul 07.00 sampai dengan 15.00. Dengan demikian tertib waktu dan tertib administrasi dapat berjalan beriringan. Dari aspek kerjasama, perilaku aparat desa dianggap baik dalam mendukung kinerja Pemerintah Desa Tumbang Kaman dalam pengelolaan administrasi desa. Meski demikian, peneliti menganggap perlu adanya standar kerja yang jelas yang dipahami dan dipatuhi bersama.

\section{Administrasi Desa}

Menurut Siagian (1991:2):"Administrasi adalah keseluruhan proses pelaksanaan dari keputusan-keputusan yang telah diambil dan pelaksanaan itu pada umumnya dilakukan oleh dua orang manusia atau lebih untuk mencapai tujuan yang telah ditentukan sebelumnya”. 
Berdasarkan hasil penelitian tersebut diatas dan pengamatan dilapangan menunjukkan bahwa Pemerintah Desa Tumbang Kaman telah menyelenggarakan pengelolaan administrasi desa dengan melibatkan seluruh aparat desa secara terbatas. Dalam hal-hal tertentu proses pelaksanaan dan pengambilan keputusan lebih banyak dilakukan oleh Kepala Desa Tumbang Kaman. Untuk aparat desa yang lain telah melaksanakan tugas-tugas administrasi desa secara terbatas dengan menggunakan alat-alat bantu manual seperti buku dan alat tulis. Untuk komputer hanya digunakan oleh Kepala Desa Tumbang Kaman.

\section{Tugas dan Fungsi Pemerintah Desa}

Menurut Zainun (1990:3-5) terdapat empat kunci pokok tugas dan fungsi administrasi dan manajemen pemerintahan Indonesia yaitu: (a) Perumusan dan penetapan kebijakan umum, (b) Kepemimpinan, (c) Pengawasan, (d) Koordinasi.

Keempat fungsi administrasi dan manajemen ini akan diterapkan pada setiap tingkat pemerintahan yang ada dalam susunan pemerintahan Negara Republik Indonesia. Berdasarkan tugas fungsi pemerintahan tersebut, berarti pemerintah desa sebagai bagian integral dari pemerintahan nasional juga menyelenggarakan fungsi-fungsi tersebut meskipun dalam ruang lingkup yang lebih sempit. Oleh unit pemerintahan desa seperti halnya pemerintah desa sebagai unit pemerintahan terendah mempunyai 3 fungsi pokok yaitu : (a). Pelayanan kepada masyarakat, (b). Fungsi operasional atau manajemen pembangunan, (c). Fungsi ketatausahaan atau registrasi (Sawe,1996:99).

Berdasarkan hasil penelitian dan pengamatan di lapangan, Pemerintah Desa Tumbang Kaman telah melaksanakan pelayanan kepada masyarakat termasuk pelayanan administrasi desa. Terkait dengan fungsi operasional atau manajemen pembangunan secara tidak langsung dapat berjalan ketika pengelolaan administrasi desa berjalan dengan baik. Ketersediaan data dan informasi yang cukup tentang Desa Tumbang Kaman tentunya akan mendukung setiap kegiatan pembangunan di Desa Tumbang Kaman. Fungsi ketatausahaan atau registrasi di Desa Tumbang Kaman masih harus terus ditingkatkan dan dirubah dari cara-cara yang manual menjadi cara yang lebih berbasis pada penggunaan komputer sebagai bagian dari sistem informasi manajemen pemerintah desa.

\section{Faktor Penghambat Pengelolaan Administrasi Desa}

Faktor penghambat sebagaimana tersebut diatas dapat diatasi dengan kemauan dari Kepala Desa untuk terus berupaya meningkatkan kemampuan dan ketrampilan stafnya dalam pengelolaan administrasi desa, khususnya kemampuan penggunaan komputer. Hal ini juga menjadi tantangan bagi Kepala Desa agar mampu menularkan pengetahuan dan ketrampilannya dalam pengelolaan administrasi desa.

Berkaitan dengan honor/gaji aparat desa yang dianggap belum mencukupi, maka perlu disampaikan permohonan kepada Pemerintah Kabupaten Katingan untuk meningkatkan honor/gaji aparat desa melalui peningkatan Alokasi Dana Desa (ADD) bagi Desa Tumbang Kaman.

\section{Faktor Pendorong Pengelolaan Administrasi Desa}

Berdasarkan faktor pendorong sebagaimana diuraikan diatas, maka seyogyanya Pemerintah Desa Tumbang Kaman dapat terus meningkatkan kinerja aparatur desa-nya dalam pengelolaan administrasi desa. Ketersediaan sarana dan prasarana yang memadai dapat menjadi modal utama dalam menyelenggarakan administrasi desa yang berkualitas. 


\section{KESIMPULAN}

Berdasarkan hasil penelitian dan pembahasan sebagaimana tersebut diatas, maka dapat ditarik kesimpulan bahwa:

1. Kinerja Aparatur Pemerintah Desa Tumbang Kaman telah terwujud dengan baik ditinjau dari aspek kualitas, kuantitas, penggunaan waktu kerja, dan kerjasama. Secara kualitas, telah teruji dan dan terbukti mendapat pengakuan dari Pemerintah Kabupaten Katingan sebagai Juara Lomba Desa. Secara kuantitas, tidak banyak dokumen yang dikelola dalam administrasi desa. Secara, penggunaan waktu kerja, cenderung kurang efektif karena masih terlalu longgar jam kerjanya. Secara kerjasama, telah berjalan dengan baik.

2. Faktor penghambat dalam pengelolaan administrasi tidak terlalu berarti, namun hal tersebut tetap ada yakni: ketrampilan aparat desa dalam hal ini Sekretaris Desa dan para Kepala Urusan (Kaur) masih perlu ditingkatkan, honor/gaji aparat desa masih perlu ditingkatkan. Faktor pendorongnya adalah ketersediaan sarana dan prasarana yang memadai di Kantor Desa Tumbang Kaman dan kerjasama yang baik telah terjalin antar aparat desa dan juga dengan masyarakat.

\section{DAFTAR PUSTAKA}

2010. Metode Penelitian Administrasi. Bandung: Alfabeta.

Beratha, I Nyoman. 1992. Desa, Masyarakat Desa, dan Pembangunan. Jakarta: Ghalia Indonesia.

ejournal.pin.or.id/site/wp.../EJURNAL\%20(02-27-13-11-34-51).pdf, diakses tanggal 16 Juli 2014.

Hatake, Ogenk. Skripsi. 2011. Upaya Peningkatan Kemampuan Aparat Desa dalam Pelaksanaan Tugas Administrasi Pemerintah Desa di Desa Watusa Kecamatan Kecamatan Puriala di Kabupaten Konawe. Konawe: Universitas Tadulako.

Mulyana, Nana dkk. Jurnal Ilmu Administrasi Negara. 2012. Peningkatan Kapasitas Aparatur Pemerintah Desa Melalui Pelatihan Manajemen Kelembagaan Desa Bagi Sekretaris Desa. Lampung: Seminar Hasil-Hasil Penelitian dan Pengabdian Masyarakat.

Pasolong, Harbani. 2007. Teori Administrasi Publik. Bandung: Alfabeta.

Peraturan Menteri Dalam Negeri Nomor 32 Tahun 2006 tentang Pedoman Administrasi Desa.

Peraturan Pemerintah Republik Indonesia Nomor 72 Tahun 2005 tentang Desa.

Rasyid, M. 1992. Pembangunan Kualitas dan Usaha-Usaha Peningkatan Aparatur Pemerintah. Palu: Universitas Tadulako

Riduwan dan Sunarto. 2009. Pengantar Statistika Untuk Penelitian. Bandung: Alfabeta.

Saparin, Sumber. 1996. Tata Pemerintahan dan Administrasi Pemerintahan Desa. Jakarta: Ghalia Indonesia.

Siagian, SP. 1991. Administrasi Pembangunan. Jakarta: Haji Masagung.

Singarimbun, Masri, dan Effendi, Sofian. 1995. Metode Penelitian Survei. Jakarta: PT. Pustaka LP3ES.

Sudarmanto. 2009. KINERJA dan PENGEMBANGAN KOMPETENSI SDM, Teori, Dimensi Pengukuran, dan Implementasi Organisasi.Yogyakarta: Pustaka Pelajar

Sugiyono. 2005. Metode Penelitian Administrasi. Bandung: Alfabeta. 
Syarif, Roesli. 1991. Teknik Manajemen Latihan dan Pembinaan. Bandung: Bina Aksara. Tjiptoherianto, Prijono. 1993. Pembangunan Sumber Daya Manusia. Jakarta: Prisma.

Undang-Undang Republik Indonesia Nomor 32 Tahun 2004 tentang Pemerintah Daerah. 